\title{
流出解析法を用いた透水性舗装への浸透連結管 付加による流出抑制効果向上の評価
}

\author{
和田安彦 ${ }^{1} \cdot$ 三浦浩之 $^{2}$ \\ ${ }^{1}$ 正会員 工博 関西大学教授 工学部土木工学科（广 564 吹田市山手町 3丁目 3-35) \\ ${ }^{2}$ 正会員関西大学助手 工学部土木工学科（干 564 吹田市山手町 3丁目 3-35)
}

\begin{abstract}
透水性舗装の雨水流出抑制効果を定量的に評価するため，水を降雨状に散水できる散水装置を用いた数十回 に及ぶ現場浸透実験と解析を実施した。これより透水性舗装における雨水浸透速度は舗装の間隙量と透水性 により決まり, 舗装面への湛水は浸透速度を増加させることが明らかになった。 また, 透水性舗装に浸透連 結管を付加することにより，透水性舗装の最終浸透能を $5 \mathrm{~mm} / \mathrm{hr}$ 程度は向上できた. 施設の浸透機構を考察 し，これに基づいて透水性舗装の雨水流出抑制効果を定量評価できる浸透・流出シミュレーションモデルを 構築した.このモデルを用いて浸透連結管を付加した透水性舗装を都市域に整備した場合の流出抑制効果を 定量評価し，浸透連結管を付加寸れば，透水性舖装を都市域の雨水排除計画に組み入れることが可能になる ことを示した.
\end{abstract}

Key Words : rainfall infiltration, storm runoff control, permeable pavement, infiltration pipe, urban runoff simulation model, tank-model

\section{1. 緒言}

現在，わが国では，都市化の進展等による都市域 の雨水流出量の增大化, 集中化に対処するため, 透 水性舗装や浸透管等の雨水浸透施設と防災調節池, 雨水貯留池, 雨水貯留管等の雨水貯留施設の設置に よる雨水流出抑制が図られている.

雨水浸透施設，貯留施設を下水道による雨水排除 計画に組み入れていくためには，これら施設の流出 抑制効果を定量的に把握することが必要である. 雨 水貯留施設の流出抑制効果の評価に関しては, 修正 R R L 法等の流出解析モデルにおいて, 流出経路で の分水機能と貯留施設の貯留機能をモデル化して組 み込み, 施設設置前と設置後の流出ハイドログラフ を比較することによって施設の流出抑制効果が推定 されている1)-7)。

一方, 雨水浸透施設の流出抑制効果は, その浸透 能が施設構造や設置地盤の浸透特性等によって異な るため, 貯留施設の貯留容量のように流出抑制量を 明確にすることが難しい。このため, ある地域全体 への浸透施設設置による流出抑制効果は, 個々の施 設の浸透実験結果等より求めた流出抑制值の単純合 計から評価するにとどまっている.

代表的な雨水浸透施設である透水性舖装は, 広い 浸透面を確保できることから都市の水循環の適正化
に役立ち，しかも，通過車両による騒音の低下，降 雨時の夜間におけるへッドライトの反射抑制等の効 果も有するため，その設置が広まれば，市民の受け る恩恵も多いと考えられる。しかし，

・浸透桝や浸透トレンチでは雨水を湛水すること により浸透能を高く維持できるが, 透水性舗装 では表面に雨水をほとんど湛水できないため, 浸透能が低い.

・通過交通によりもたらされる土粒子やゴミ等が 多く, 目詰まりによる浸透能低下の問題が顕著 に表れる.

といった問題点があるため, その普及が関東（とり わけ東京都）以外では遅れているのが現状である.

そこで, 本論文では, 透水性舗装の浸透能力を向 上させるために, 浸透連結管を付加することを試み, その流出抑制能力と雨水浸透機構を実験施設におけ る浸透実験より明らかにする.さらに，この施設を 排水区域全体に設置した場合の流出抑制効果を，流 出解析モデルにより評価する.

\section{2. 浸透連結管付き透水性舗装とその透水特性}

\section{（1）浸透連結管付き透水性舗装}

浸透連結管付き透水性舗装は，側溝の下部に浸透 連結管を併設して，透水性舗装の路床に浸透した雨 水を排除することにより，透水性舗装の浸透能を降 


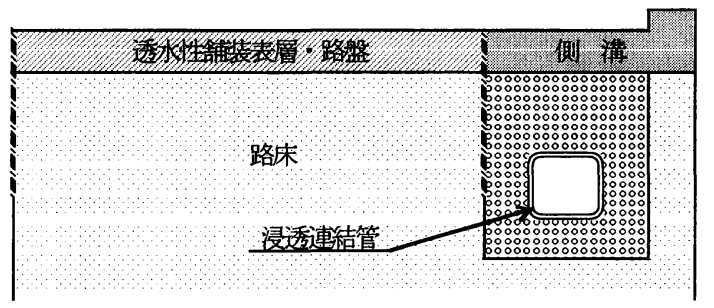

図一１浸透連結管付き透水性舗装施設の構造図

雨後半においても高く維持することを目指した施設 である（図ー1）。透水性舗装と浸透連結管の間に は地表面より $0.59 \mathrm{~m}$ まで止水板（エラスタイト厚さ $10 \mathrm{~mm}$ ）が埋設してあり, 透水性舗装より地中へ浸透 した雨水がすぐに浸透連結管内へ浸透することを防 いでいる.

透水性舗装表面は緩やかに傾斜しており, 浸透し きれずに表面に湛水した水は舗装面端に設置した流 出孔へと流出するようになっている. ここで表面流 出量を計測する. また, 浸透連結管は桝に接続して おり,ここで流出量を計測する.

これまでに，試験的に設置した透水性舗装に次の 3 タイプの浸透連結管を付加した複合型雨水浸透施 設の雨水流出制御効果について浸透実験を通じて明 らかにしてきた ${ }^{8)-11)}$.

Type-1 ; ポーラスコンクリート管 (円形)

Type-2 ; ポーラスコンクリート管（方形）

Type-3 ; 有孔塩化ビニール管 (卵型)

実験時の地下水位や路床土壌の湿潤状態の方が施 設構造よりも浸透速度等に対する影響が大きく, 付 加する浸透連結管のタイプによる浸透能の差は見ら れなかった。

さらに, 実験結果の検討により明らかにした複合 型雨水浸透施設の雨水浸透機構をもとに, 施設の雨 水制御効果を予測評価するシミュレーションモデル を構成した. 複合化した雨水浸透施設の雨水浸透機 構は, 多段タンクモデルを応用したモデルにより表 現できた ${ }^{11)}$. なお, 実験地には浸透連結管のみを設 置したタイプもある.

\section{（2）実験方法}

\section{a) 浸透実験 I：浸透連結管付き透水性舗装}

浸透連結管を付加した透水性舗装における浸透実 験を次のように行った.

透水性舖装表面に降雨散水装置で一様な降雨強度 で散水し, 表面流出開始までの時間と累積散水量, 及び, 表面流出開始後の流出量の測定を行った ${ }^{11)}$. 降雨散水装置は塩化ビニルパイプ製で, 散水孔の間 隔, 孔径を工夫することで, 舗装面全体の散水強度
が極力一様になるようにしたものである．実験では これを複数個用い, 舖装面での降雨強度が一様にな るように, 適宜装置を移動した.

一般に透水性舗装での散水実験による表面流出水 量は散水初期は発生せず，ある時間経過後に流出を 開始する.この表面流出開始までの単位面積当たり の累積散水量を初期浸透高とした。 流出開始後, 表 面流出量は徐々に増加し, その後, ある值で一定と なる.この時の浸透速度を最終浸透能とした.

さらに, 透水性舗装表面からの流出量がほぼ一定 となっても散水を継続した.これにより，透水性舗 装に併設された浸透連結管からも流出が始まる.こ の流出量が流出閉始後より増加し, その後, ある值 で一定となるまで実験は継続した.

\section{b) 浸透実験 II：浸透連結管付加効果の検討}

実験施設には透水性舗装のみで浸透連結管を付加 していないものはない.このため, 直接, 浸透実験 により浸透連結管を透水性舗装に付加することの効 果を明らかにすることはできない，そのため，あら かじめ浸透連結管を水で満たし，透水性舗装に浸透 した水が浸透連結管へ流入しない状態を意図的に作 って、散水実験を行い、浸透連結管が付加されてい ない透水性舗装の浸透特性を調査した.

\section{c) 浸透実験III：浸透連結管}

浸透連結管単独でも浸透実験を行った。実験は浸 透連結管の下流端は開放し, 上流端を締め切って注 水し, その反対側で流出量を測定する方法（流水法） で行った. 通常, 浸透連結管の浸透能力調查に用い られている定水位法などの湛水方式を用いなかった のは, 対象実験施設での浸透連結管の機能が, 連結 管内に流入した雨水を浸透させつつ, 域外一排除す ることであるためである.

浸透連結管では透水性舗装における散水強度に該 当するものとして注水強度を用いた。これは単位時 間内の浸透連結管への注水量を浸透連結管の浸透面 当たりに換算したものである.また, 初期浸透高, 最終浸透能の值もこの浸透面積を用いて算出した.

\section{（3）透水性舖装の浸透特性 \\ a) 実験結果}

実験結果を表ー 1 に示す。ここで, 浸透連結管無 しの場合とは, 浸透実験 IIによる調査結果である.

散水強度等の実験条件の違いはあるものの, 浸透 連結管を付加することによって最終浸透能が 4-5 $\mathrm{mm} / \mathrm{hr}$ 高くなっている.

実験における透水性舗装表面流出ハイドロ, 浸透 連結管流出ハイドロの一例を図ー2に示す。透水性 舗装への散水により、浸透連結管からも流出が生じ 
表-1 透水性舖装浸透能調查結果 （平均值）

\begin{tabular}{l|l|rccc}
\hline & $\begin{array}{l}\text { 浸透 } \\
\text { 連結 } \\
\end{array}$ & $\begin{array}{c}\text { 実験 } \\
\text { 管 }\end{array}$ & $\begin{array}{l}\text { 平均 } \\
(\text { 回 })\end{array}$ \\
$\begin{array}{l}\text { 散水強度 } \\
(\mathrm{mm} / \mathrm{hr})\end{array}$ & $\begin{array}{c}\text { 初期 } \\
\text { 浸透高 } \\
(\mathrm{mm})\end{array}$ & $\begin{array}{l}\text { 最終 } \\
\text { 浸透能 } \\
(\mathrm{mm} / \mathrm{hr})\end{array}$ \\
\hline Type-1 & 有り & 11 & 43 & 34 & 29 \\
& 無し & 4 & 41 & 22 & 25 \\
\hline Type-2 & 有り & 12 & 54 & 32 & 40 \\
& 無し & 4 & 43 & 44 & 35 \\
\hline 全タイプ & 有り & 12 & 58 & 35 & 37 \\
& 無し & 3 & 43 & 34 & 33 \\
\hline & 有り & 35 & 48 & 34 & 35 \\
& 無し & 11 & 42 & 33 & 30 \\
\hline
\end{tabular}

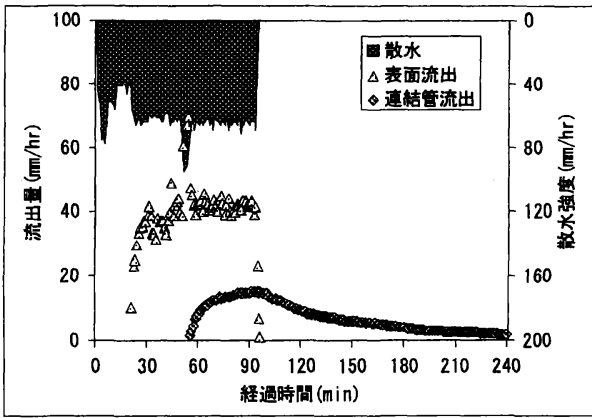

図ー2 浸透実験における流出ハイドログラフ

ており，透水性舗装の路床一浸透した水の一部が浸 透連結管へ流入して，さらに管を通じて区域外へ流 出している.この流出は散水停止後徐々に減少して, やがて終了する.

図一３は実験における平均的な水収支を計算した 結果は表したものである. およそ散水した水の $70 \%$ が透水性舗装より浸透し，この内の $30 \%$ が浸透連結 管より区域外一流出している.

以上より，透水性舗装より路床一と浸透した水の 一部は併設した浸透連結管へ流入し，区域外一と流 出していると判断できる。この現象を本論文では側 方浸透として取り扱う。

\section{b) 初期漫透高}

図一 4 に各実験時の平均散水強度と初期浸透高の 関係を示す。

通常, 浸透施設における初期浸透高は降雨強度に 関係なく一定値になると考えられている。しかし， 解析結果では, 初期浸透高は散水強度が強いほど小 さな值となる傾向を示している.

次に, 初期浸透高を求める際に用いる表面流出開 始までの時間と, 平均散水強度の関係を求めた。こ れを図ー 5 に示す。さらに，相関の高い関係が得ら れており $(\mathrm{R}=0.71)$, 透水性舗装からの表面流出の発 生は降雨強度が強まると急速に早くなることがわか る.

以上の特性は，表面流出が開始するまでは，
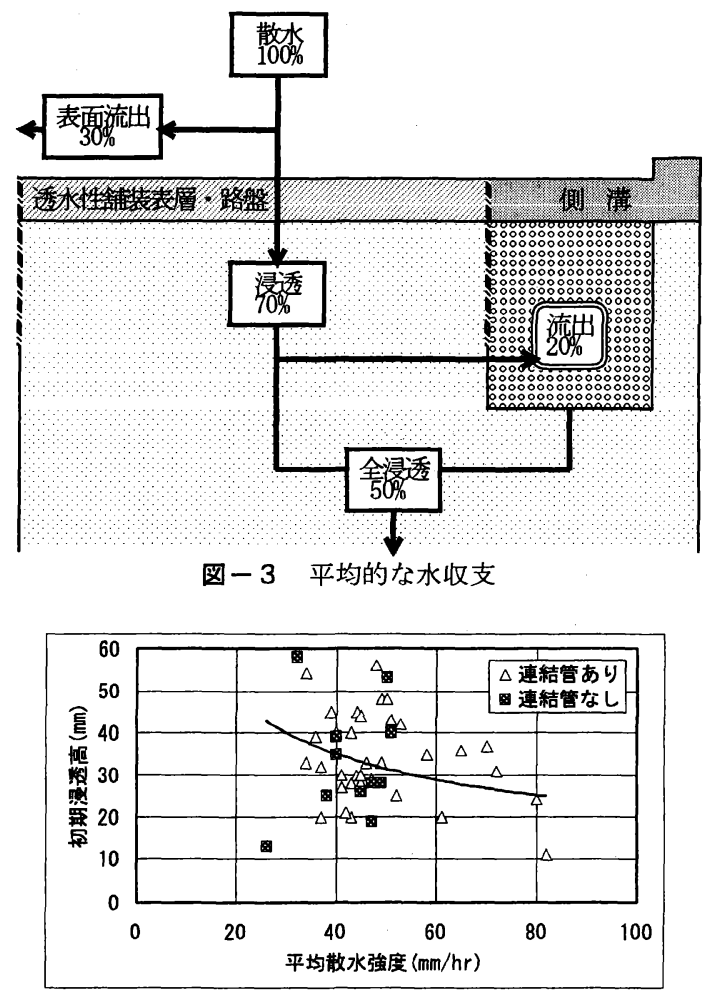

図-4 平均散水強度と初期浸透高の関倸

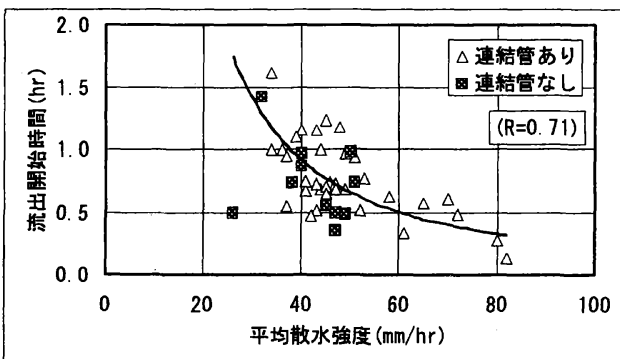

図－5平均散水強度と流出開始時間の関係

(1)舗装の表層・路盤から路床への浸透

(2)舗装の表層・路盤の間隙への貯留 が同時に進行していると考えると説明できる.

すなわち，これら 2 つ事象が同時に進行してい るとすると, 平均散水強度, 流出開始時間, 舖装表 層・路盤の間隙量, 浸透速度の間には次の関係式が 成り立つ.

$$
t=H /(R-S H)
$$

ここで, $t$ は流出開始時間 $(\mathrm{hr}), \quad R$ は平均散水強度 $(\mathrm{mm} / \mathrm{hr}), H$ は透水性舖装表層・路盤の単位面積当 たりの間隙量 $(\mathrm{mm}), \quad S H$ は表面流出開始までの浸 透速度 $(\mathrm{mm} / \mathrm{hr})$ である. 


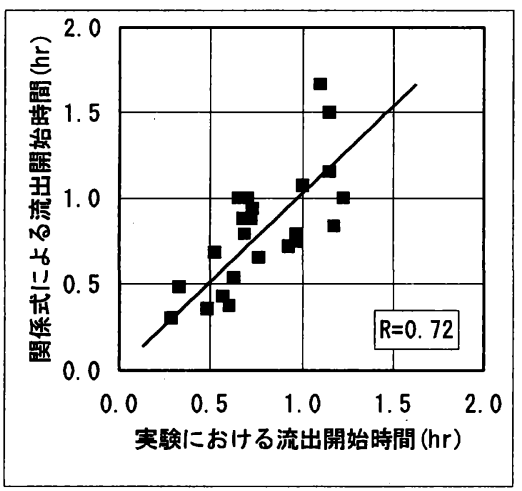

図－6 舖装表層・路盤間隙量 $\mathrm{H}$ と浸透速度 $\mathrm{SH}$ の推定 $(\mathrm{H}=15 \mathrm{~mm}, \mathrm{SH}=30 \mathrm{~mm} / \mathrm{hr})$

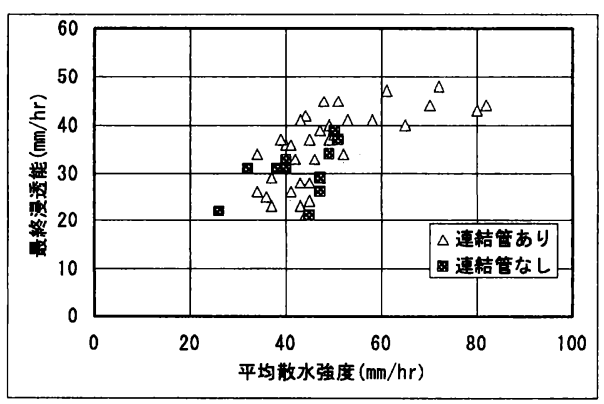

图- 7 平均散水強度と最終浸透能の関係

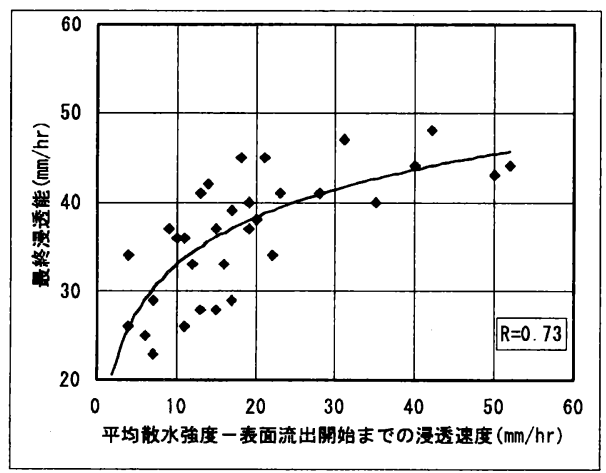

図-8 平均散水強度と最終浸透能の関係 （舗装の浸透速度考慮）

$H=15 \mathrm{~mm}, \quad S H=30 \mathrm{~mm} / \mathrm{hr} \quad$ として算出した流 出開始時間と実験時の流出開始時間の関係を図-6 に示す. 両者の相関係数は 0.72 であり, 先の仮定が 妥当であったと判断できる（ただし，平均散水強度 $80 \mathrm{~mm} / \mathrm{hr}$ 程度以下の範囲）。

したがって，透水性舖装において見かけ上の初期 浸透高は一定値ではなく, 降雨強度により変化する と評価できる.

\section{b) 最終浸透能}

次に, 平均散水強度と最終浸透能の関係を図ー 7
に示す. 最終浸透能は浸透施設による流出抑制効果 の評価に用いられ，その値は設置地盤の透水特性と 施設形状により決まるものとされている.

これについても，対象施設ではデータのばらつき はあるものの, 降雨強度が強くなると最終浸透能が 高くなる傾向が見られた。これは，実験において， 散水強度を時間降雨量で $40 \sim 70 \mathrm{~mm} / \mathrm{hr}$ 程度と強く 設定しており，これによって浸透しきれない水が表 面に数 $\mathrm{mm} \sim 1 \mathrm{~cm}$ 程度であるが湛水しており，この 表面湛水により舗装表層の上面と下面に作用する圧 力差が大きくなり，その分だけ動水勾配が大きくな って浸透速度が大きくなっていると考えられる.

この仮定を証明するため，実験結果より，平均散 水強度と最終浸透能の関係を図化した. 解析結果を 図ー8に示す。ここでは，先に求めた表面流出開始 までの浸透速度 $S H$ を基準値として解析した。

この図より, 平均降雨（散水）強度が表面流出開 始までの浸透速度 $S H$ より強い場合には, 最終浸透 能は散水強度が強いほど高い值となることが読みと れる.

したがって，透水性舗装の浸透機構のモデル化に 当たっては, 表面への湛水による浸透能の増加を考 慮する必要がある.

\section{(4) 漫透連結管の浸透特性}

筆者らは浸透式の雨水管きょにおける浸透特性を

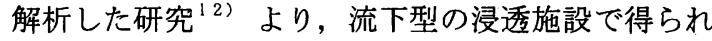
る浸透能は施設一の流入水量, 寸なわち流下水深に 比例することを明らかにしている。

そこで，浸透連結管においても，同様な浸透特性が みられると予想し, 流下水深の代わりに注水強度を 用い, 最終浸透能との関係を解析した，両者の関係 を次の図ー9に示す.データのばらつきはあるもの の, 注水強度が強いほど得られる最終浸透能の值が 大きくなっている. そこで, 注水強度と浸透率（= 最終浸透能／注水強度）の関係についても図化した。 これを図ー10に示す.浸透連結管の浸透率はおよそ $0.05 \sim 0.3$ (平均 0.15 ）の範囲にある.

\section{3. 浸透連結管付き透水性舗装の浸透機構とモ デル化}

\section{(1) 浸透機構}

従来の筆者らの研究において，対象施設の浸透機 構の模式化は行っている ${ }^{11)}$ が, さらに解析を進め た結果, 浸透機構の解明において浸透面の位置を考 慮する必要があると判断して, 従来の考えに若干の 修正を加え，その浸透機構を図一11のように考えた。 


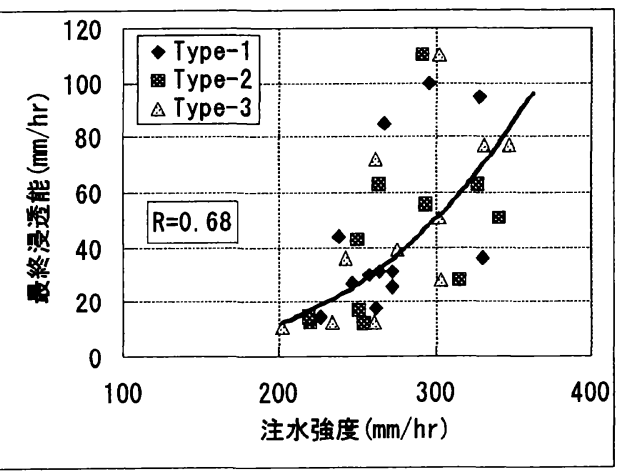

図－9 浸透連結管の最終浸透能

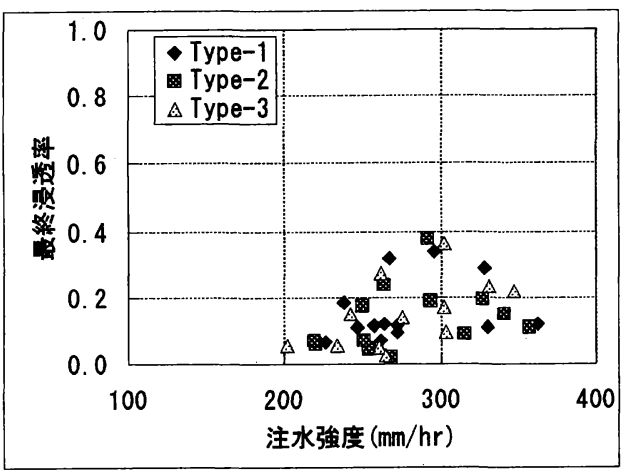

図-10 浸透連結管の最終浸透率

(1)降水 $\rightarrow$ 透水性舖装の表層・路盤

透水性舗装表面への降水は表層 - 路盤の間隙 に貯留されながら浸透し, さらに路床へと浸透 していく．この表層・路盤における浸透の速度 は表層・路盤が不飽和状態の場合と飽和状態の 場合では異なる．表層・路盤を浸透（間隙への 貯留含む）しきれなかった降水は表面流出とな る.

(2)透水性舗装の路床一浸透連結管

表層・路盤内を浸透した降水（浸透水）は路床 を浸透する．浸透速度は設置地盤固有の值をと る.

路床を浸透水が浸透していく際, 湿潤線が形 成され，これが次第に路床の下方へと移ってい く.この湿潤線が透水性舗装と浸透連結管を分 離している止水板の下端にまで到達すると浸透 水は浸透連結管設置地盤へも拡がっていく.

この側方浸透現象は鉛直方向で見て，止水板 下端から浸透連結管の浸透面までの間にある路 床にある浸透水により生じる，そこで，この側 方浸透に関与する路床部を路床 2 とし，それよ り上方を路床 1 ，下方を路床 3 と区分して考え る(図-12）。

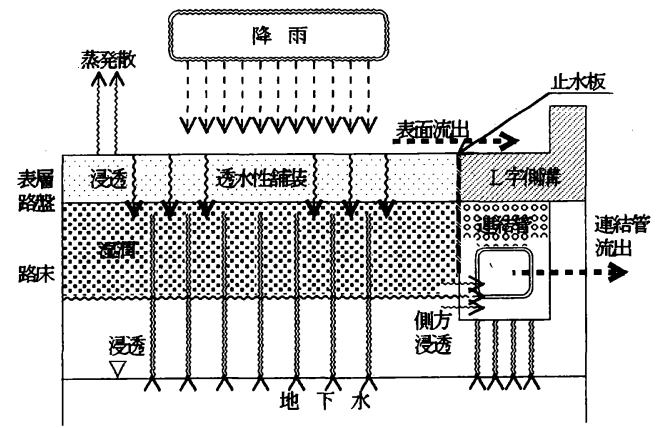

図ー11浸透機構のイメージ

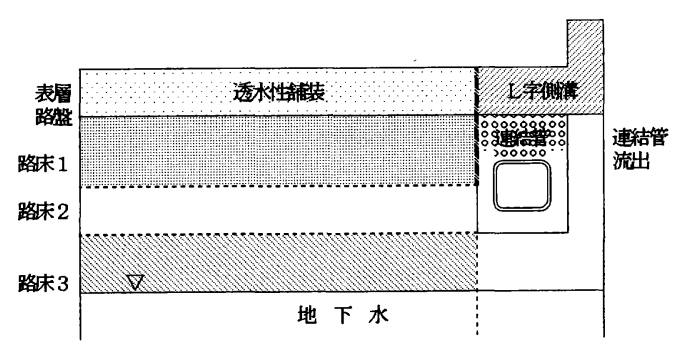

図ー12 浸透施設のモデル化

路床 3 に達した浸透水はさらに下方の地下水 面まで浸透していく．したがって，ここまで達 した浸透水は流出することはない.

(3)浸透連結管

路床 2 部分の浸透水の一部が側方浸透現象に より浸透連結管周囲の地盤及び砕石部へと移動 する.

側方浸透水はこの地盤と砕石部の間隙を満た していきながら，下方へと浸透する．側方から の浸透量よりも下方への浸透量が少なければ, 浸透連結管周囲の地盤・砕石部の間隙での貯留 水量が増え，すべてを満たしきると浸透連結管 内へと浸透して外部へと排除されていく.

浸透連結管は透水性舗装の路床部の浸透水の一部 を外部一排除している.これにより, 路床部間隙が 飽和状態になることを遅くし, 施設の最終浸透能の 向上に奇与している.

\section{(2) 複合雨水浸透型施設の浸透機構のモデル化}

以上の浸透機構を流出解析に用いられるタンクモ デルの考え方を応用してモデル化した．モデルのイ メージ図を図ー13に示す．施設の各部分をひとつの タンクに置き換えてモデル化している。これは筆者 らが構築した対象施設のシミュレーションモデルを ベースに，新たに解明できた浸透機構を考慮して， 再構筑したものである.

\section{a) 表層・路盤}




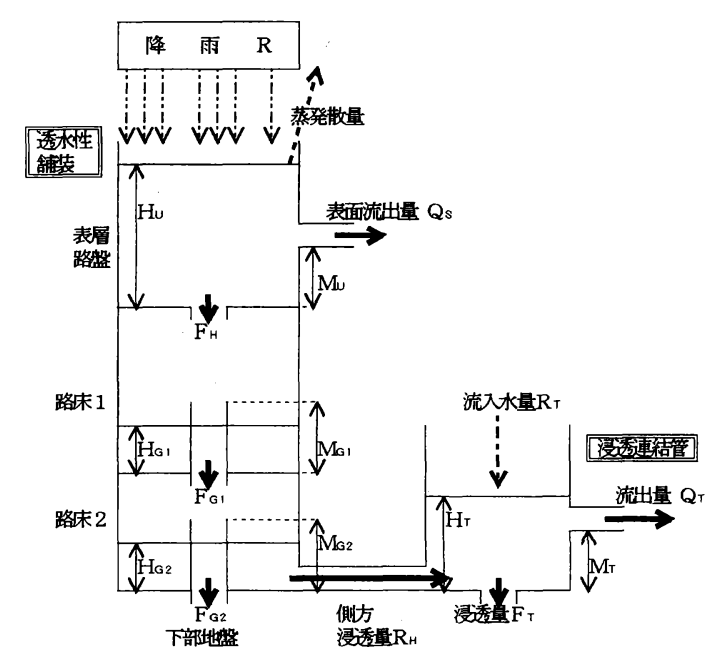

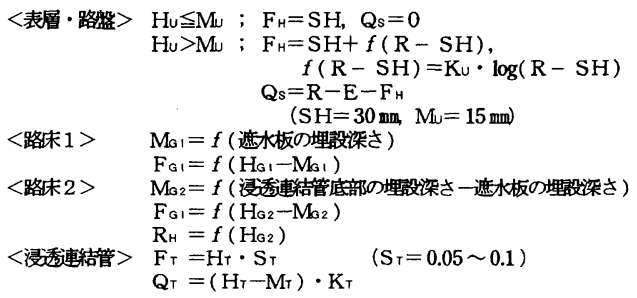

図-13 浸透施設の浸透機構のモデル化

透水性舖装の表層・路盤では間隙への貯留と浸透 が同時に行われ，その浸透速度は降雨強度に比例す る. そこで, 表層・路盤は表層・路盤の単位面積当 たりの間隙量を流出孔の高さとするタンクで表現す る. 上述の解析結果より透水性舗装の表層・路盤の 間隙量は $15 \mathrm{~mm}$ であることから, タンクの流出孔高さ は $15 \mathrm{~mm}$ とする.

浸透速度は, 降雨強度が強い場合には表面湛水に より透水性舗装の最終浸透能が $30 \mathrm{~mm} / \mathrm{hr}$ 以上となる ことから, 次式により表した。

$$
f s=f s o+f s a
$$

ここで, fs は表層・路盤の浸透速度，fso は表層・ 路盤固有の浸透速度, $f s a$ は表面湛水による付加的 浸透速度である.

最終浸透能と平均降雨（散水）強度には比例関係 が見られることから，両者の関係を表す次の回帰式 を求めた.

$$
\begin{aligned}
& f m=f-f s o \\
& R m=R-f s o
\end{aligned}
$$$$
f m=24.9 \cdot \log R m-21.27
$$$$
(R=0.73)
$$

ここで, $f m$ は補正最終浸透能 $(\mathrm{mm} / \mathrm{hr}), \quad R m$ は補正 降雨強度 $(\mathrm{mm} / \mathrm{hr}), f$ は最終浸透能 $(\mathrm{mm} / \mathrm{hr}), \quad R$ は
平均降雨強度 $(\mathrm{mm} / \mathrm{hr})$ である.

したがって，表層・路盤のタンクモデルにおける 浸透速度 $F_{\mathrm{H}}$ および表面流出量 $Q \mathrm{~s}$ は次式で表現す る.

$$
\begin{aligned}
& H \cup \leqq M_{\cup}\left\{\begin{array}{l}
F_{\mathrm{H}}=S_{\mathrm{H}} \\
Q{ }_{\mathrm{S}}=0 \\
H_{\mathrm{U}}=H_{\mathrm{U}}{ }^{\prime}+r-S_{\mathrm{H}}
\end{array}\right. \\
& H_{\mathrm{U}}>M_{\cup}\left\{\begin{array}{l}
F_{\mathrm{H}}=S_{\mathrm{H}}+24.9 \cdot \log \left(r-S_{\mathrm{H}}\right)-21.27 \\
Q_{\mathrm{S}}=r-E-F_{\mathrm{H}} \\
H_{\mathrm{U}}=H_{\mathrm{U}}{ }^{\prime}+r-S_{\mathrm{H}}-Q_{\mathrm{S}}
\end{array}\right.
\end{aligned}
$$

ここで, $\quad r$ は降雨強度 $(\mathrm{mm} / \mathrm{hr}), \quad M$ Uは表層・路盤 の間隙量 $(\mathrm{mm}), \quad H \cup$ U表層・路盤の間隙への貯留量 $(\mathrm{mm}), \quad F_{\mathrm{H}}$ は路床 1 への浸透量 $(\mathrm{mm} / \mathrm{hr}), \quad S_{\mathrm{H}}$ は表 層・路盤固有の浸透速度 $(\mathrm{mm} / \mathrm{hr}) \quad(=30 \mathrm{~mm} / \mathrm{hr})$, $Q$ sは表面流出量 $(\mathrm{mm} / \mathrm{hr}), \quad \mathrm{E}$ は蒸発散量 $(\mathrm{mm} / \mathrm{hr})$ で ある。蒸発散量は実験施設と同一のアスファルト試 験ピースに散水し, 総重量の変化によって測定した.

b) 路床 1

路床 1 の浸透機構を表すタンクの浸透孔高さは, 路床 1 の単位面積当たりの間隙量 $M_{\mathrm{G} 1}$ である.

路床 2 人の浸透量 $F_{\mathrm{G}}$ は次式で表現する.

$$
\left\{\begin{array}{l}
H_{\mathrm{G} 1}=H_{\mathrm{G} 1}{ }^{\prime}+F_{\mathrm{H}} \\
F_{\mathrm{G} 1}=H_{\mathrm{G} 1}-M_{\mathrm{G} 1}
\end{array}\right.
$$

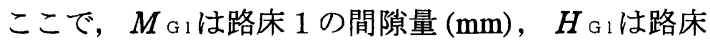
1 の間隙への貯留量 $(\mathrm{mm}), F_{\mathrm{G}} 1$ は路床 2 への浸透 量 $(\mathrm{mm} / \mathrm{hr})$ である.

c) 路床 2

側方浸透は浸透水が路床 2 に達すると直ぐに生じ ると考え, タンクの側方浸透孔（流出孔）高さは0 $\mathrm{mm}$ とする. 路床 3 一の浸透孔高さは路床 1 同様に路 床 2 の単位面積当たりの間隙量 $M_{\mathrm{G} 2}$ である.

路床 3 への浸透量 $F_{\mathrm{G} 2}$, 側方浸透量 $R_{\mathrm{H}}$ はそれぞ れ次式で表現する.

$$
\left\{\begin{array}{l}
H_{\mathrm{G} 2}=H_{\mathrm{G} 2}{ }^{\prime}+F_{\mathrm{G} 1} \\
F_{\mathrm{G} 2}=H_{\mathrm{G} 2}-M_{\mathrm{G} 2} \\
R_{\mathrm{H}}=F \boldsymbol{r} \cdot H_{\mathrm{G} 2}
\end{array}\right.
$$

ここで, $M_{\mathrm{G} 2}$ は路床 2 の間隙量 $(\mathrm{mm}), H_{\mathrm{G} 2}$ は路床 2 の間隙への貯留量 $(\mathrm{mm}), F_{\mathrm{G} 2}$ は路床 3 一の浸透 量 $(\mathrm{mm} / \mathrm{hr}), \quad R$ нは側方浸透量 $(\mathrm{mm} / \mathrm{hr}), \quad F r$ は側方 浸透係数である.

\section{d) 浸透連結管}

流出孔高さを浸透連結管下部の砕石層の単位面積 当たりの間隙量と浸透連結管の浸透面より地下水面 までにある地盤の単位面積当たりの間隙量との和と した. また, 浸透量は砕石部間隙の貯留水量に比例 するため, 実験結果より求めた浸透率を浸透係数と する浸透孔で表す．なお，浸透連結管には透水性舗 装の路床に浸透した浸透水の一部が浸透する他に， 
表一2 対象浸透施設のモデルにおける特性值

\begin{tabular}{l|ccc}
\hline \multicolumn{1}{c|}{ 特性值 } & Type-1 & Type-2 & Type-3 \\
\hline Mu (mm) & $5-10$ & $10-15$ & $10-15$ \\
Mgu (\%) & 5 & 5 & 5 \\
SH3 $_{\text {(mm } / \mathrm{hr})}$ & $10-15$ & 5 & $10-15$ \\
Fr (-) & 0.3 & 0.3 & 0.3 \\
Mtu(\%) & 15 & 15 & 5 \\
Kt (-) & 0.7 & 0.7 & 0.6 \\
St (-) & 0.05 & 0.05 & 0.05 \\
\hline
\end{tabular}

直接管内一流入する雨水もあるため, これも考慮で きるようにした。

モデルの基礎式を次に示す.

$$
\left\{\begin{array}{l}
H_{\mathrm{T}}=H_{\mathrm{T}}{ }^{\prime}+R_{\mathrm{H}} \cdot\left(A_{\mathrm{T}} / A_{\mathrm{H}}\right)+R_{\mathrm{T}} \\
F_{\mathrm{T}}=H_{\mathrm{T}} \cdot S_{\mathrm{T}} \\
Q_{\mathrm{T}}=\left(H_{\mathrm{T}}-M_{\mathrm{T}}\right) \cdot K_{\mathrm{T}}
\end{array}\right.
$$

ここで， $M_{\mathrm{T}}$ は浸透連結管砕石部・地盤の間隙量 $(\mathrm{mm}), H_{\text {T }}$ 砕石部・地盤の間隙への貯留量 $(\mathrm{mm})$, $R$ Tは浸透連結管への直接流入水量 $(\mathrm{mm} / \mathrm{hr}), F_{\text {T }}$ は

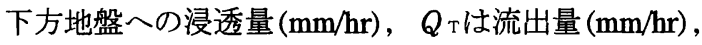
$A$ 斤 は浸透連結管の設置面積 $\left(\mathrm{m}^{2}\right), A_{\mathrm{H}}$ は透水性舗 装の設置面積 $\left(\mathrm{m}^{2}\right), \quad S_{\text {Tは流出係数, } K_{\mathrm{T}} \text { は浸透係 }}$ 数 (־実験時の浸透率) である.

\section{4. 浸透連結管付加の効果の評価}

\section{（1）モデルシミュレーション}

構築したモデルを用い，実測した透水性舖装表面 流出量と浸透連結管流出量にシミュレーション結果 が一致するように次の特性值の決定を行った.

(1) 透水性舗装表層・路盤の間隙量 $M \mathrm{U}(\mathrm{mm})$

(2)路床の間隙率 $M g u(\%)$

(3)路床の浸透速度 $S_{\mathrm{H} 3}(\mathrm{~mm} / \mathrm{hr})$

(4)浸透連結管への側方浸透率 $F r(-)$

(5)浸透連結管の砕石部等の間隙率 $M t u(\%)$

(6)浸透連結管の流出率 $K t(-)$

(7)浸透連結管の浸透率 St $(-)$

ここで,これら特性值は対象施設の各タイプ毎の 固有值であると考え，定数となるように配慮した． ただし, 透水性舗装表層・路盤の間隙量は気象条件 等の影響を受けるためある範囲内で適切な值を設定 した.

また，路床と浸透連結管の砕石部等の間隙量では なく間隙率を特性值としているのは，間隙量は地下 水位のレベルにより対象となる路床厚および砕石部 の地盤厚が変化するため, 間隙率とこれらの厚さか ら間隙量を求めるようにしたためである.

すべての実験データに対して特性值同定シミュレ ーションを行った結果, 各特性值はタイプ別に表一 2 に示すように求められた.

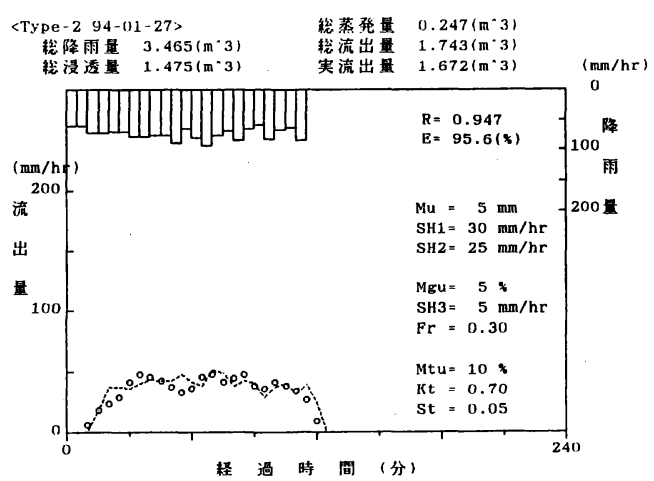

図ー14(1) 透水性舗装部のシミュレーション結果

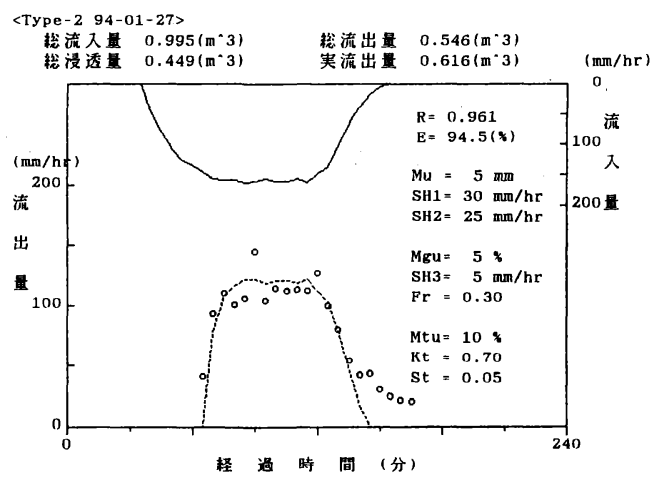

図ー14(2) 浸透連結管部のシミュレーション結果

これら特性値から見ても，浸透連結管を透水性舗 装の路床部浸透水の排除用に用いた場合には，流出 抑制上の機能に関しては浸透連結管の種類はあまり 影響しないと判断できる.

シミュレーション結果の一例を図ー14に示す．同 定シミュレーション結果は, この図で示しているよ うに透水性舖装での表面流出量の変動状況および浸 透連結管からの流出量の変動状況を的確に再現でき ている.

\section{（2）浸透連結管付加効果の評価}

同定シミュレーション結果が的確であり，モデル 中の未知の特性值も各施設タイプ毎に定数値として 得られたため, これを用いて浸透連結管付加の効果 を検討した，すなわち，先のモデルにおいて浸透連 結管への側方浸透率を0 として, 同じ降雨条件を用 いてシミュレーションを実施した.

シミュレーション結果の一例を図ー15に示す. 降 雨後半において透水性舗装表面からの流出水量が増 えていることがわかる、これは他の降雨条件におい ても同じであり, 浸透連結管の付加は透水性舗装の 透水能力の長時間に渡る確保に寄与すると評価でき る. 特に実験における降雨強度が平均 $40 \sim 60 \mathrm{~mm} /$ 


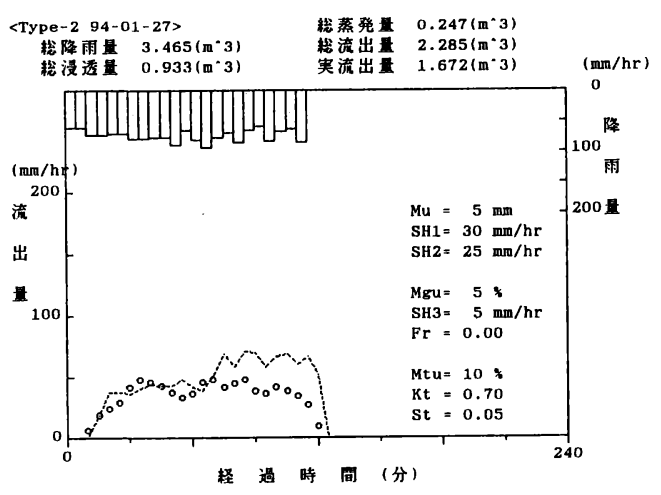

図ー15(1) 透水性舗装部のシミュレーション結果

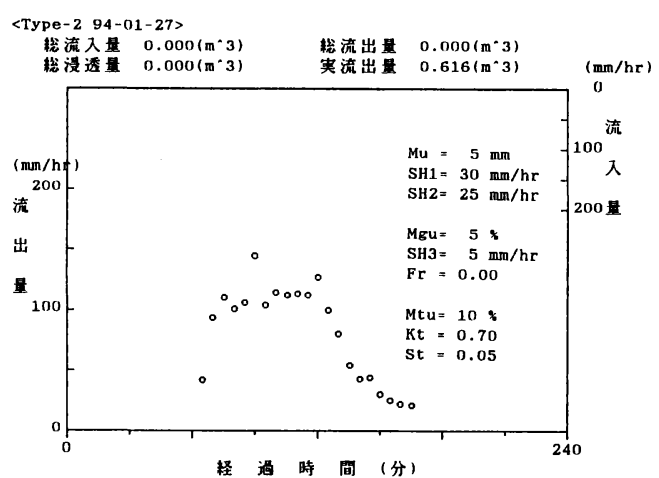

図ー15(2) 浸透連結管部のシミュレーション結果

$\mathrm{hr}$ で，しかもその強度で 2 時間以上継続させたもの であることを考えると, 浸水発生が危惧される豪雨 時における雨水浸透による流出抑制が十分可能であ ると考えられる.

現在, 透水性舗装はその浸透能力が不安定である ため, 雨水排除計画の立案時等において, 流出抑制 施設としてほとんど考慮されていない。しかし，わ れわれが検討した施設のように浸透連結管を付加す れば，その浸透能力を高めることが可能である.さ らに, 貯留施設の貯留量が一杯となる豪雨時の降雨 後半においても流出抑制機能を保持できることは高 く評価できる.

\section{5. 流域規模での浸透施設設置効果の評価}

\section{（1）評価手法}

筆者らはこれまで透水性舗装や各種の雨水貯留施 設, および流出系での流出抑制施設である浸透性雨 水管きょを流域内に適宜設置した場合の流出抑制効 果の評価手法について研究してきた ${ }^{13)-15)}$ 。筆者ら が提案してきた手法は, 都市域の雨水流出ハイドロ グラフを求める際に一般的に用いられている修正
RRL 法 ${ }^{16)-19)}$ における有効降雨モデルに, 各流出 抑制施設の流出抑制機構を個々に組み込むものであ る.

これまで，筆者らは，各流出抑制施設の流出抑制 能力を凹地貯留と同様な貯留高と浸透域の浸透速度 と同様な浸透能で表現してきた. しかし，本研究で 対象とした施設の流出抑制能力は，このような定数 值で表せるような単純なものではないため, 有効降 雨モデルに先の対象施設の流出・浸透シミュレーシ ヨンモデルを組み込んだ.

対象域を次の 5 タイプに区分し，浸透施設設置域 についてはシミュレーションモデルにより流出量を 算出し, これを有効降雨量とした.

$$
\left[\begin{array}{l}
\text { 浸透域 } \leftarrow \text { 直接流出域 } \\
\text { 不浸透域 } \longrightarrow \text { 面接流出域 } \\
\text { 浸透施設設置域 }
\end{array}\right.
$$

さらに，対象施設の設置場所や設置面積を的確に 評価するため, 有効降雨量を各等到達時間域毎に算 出し, 次式を用いて有効水量を算出して, インフロ 一ハイドログラフを求める.

$$
P(t)=R_{n(1)} \cdot A_{n}+R_{n-1(2)} \cdot A_{n-1}+\cdots+R_{1}(t) \cdot A_{1}
$$

ここで, $P(t)$ は計算ステップ $t$ における有効水量, $R_{n}(t)$ は $t$ ステップにおける等到達時間域 $n$ の有効降 雨量, $A n$ は等到達時間域 $n$ の面積である.

\section{（2）モデル地域における評価}

提案する手法を用いて，ある流域一の対象浸透施 設を設置した場合の流出抑制効果を流域単位で評価 する.

\section{a) 対象モデル地域}

対象モデル地域は都市化された分流式下水道整備 区域で，面積は $10.39 \mathrm{ha}$ である，不浸透面積率は $53.4 \%$ \%゙あ.

\section{b) 対象降雨}

対象降雨には計画降雨（確率年 $1 / 10$, 中央ピーク 型）を用いた.

総降雨量 $72.9 \mathrm{~mm}$ 時間最大 $172 \mathrm{~mm} / \mathrm{hr}$ 地下水位は対象降雨日に測定された現地での值を 参考に設定した.

\section{c) 施設設置条件}

対象地域の幹線道路以外の全ての道路に, 対象浸 透施設を設置することを想定した．対象モデル地域 内の幹線道路以外の道路の総面積は $1.652 \mathrm{ha}$ であり, 道路総延長は約 $3,300 \mathrm{~m}$ である.

また，実験施設では道路の片端に浸透連結管が設 置してあるものであったが, ここでは道路の両側下 に浸透連結管を設置することを想定した。したがっ 
表ー 3 浸透施設の浸透特性設定值

\begin{tabular}{l|c}
\hline \multicolumn{1}{c|}{ 特性值 } & 設 定 值 \\
\hline $\mathrm{Mu}(\mathrm{mm})$ & 15 \\
$\mathrm{Mgu}(\%)$ & 5 \\
$\mathrm{~S}_{\mathrm{H} 3}(\mathrm{~mm} / \mathrm{hr})$ & 10 \\
$\mathrm{Fr}(-)$ & 0.3 \\
$\mathrm{Mtu}(\%)$ & 15 \\
$\mathrm{Kt}(-)$ & 0.7 \\
$\mathrm{St}(-)$ & 0.05 \\
\hline
\end{tabular}

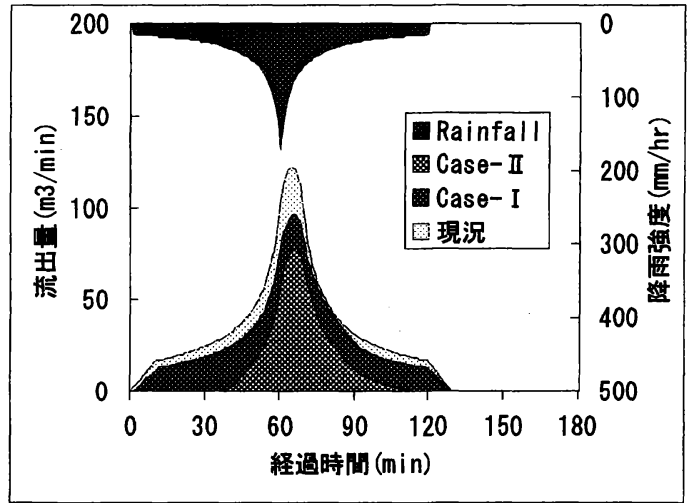

図-16 対象排水区からの流出ハイドログラフ

て，浸透連結管の総延長は約 $6,600 \mathrm{~m}$ となる. 検討ケースは

I：透水性舗装のみ設置

II：透水性舗装に浸透連結管を付加

の 2 ケースである.

\section{d) 流出抑制効果の検討}

浸透施設の浸透特性値は表ー 3 に示す同定シミュ レーションにおける平均的な值を用いた。

対象地域からの流出ハイドログラフを図ー16に示

す. 雨水浸透施設の流出抑制効果を総流出量の低減 率 $\triangle T Q d / T Q 0$ とピーク流量の低減率 $\triangle P Q d / P Q o$ で表 し, 各検討ケースで求めた結果を表一 4 に示す.

$$
\begin{aligned}
& \triangle T Q d / T Q o=(T Q o-T Q s) / T Q o \\
& \triangle P Q d / P Q o=(P Q o-P Q s) / P Q o
\end{aligned}
$$

ここで, $\triangle T Q d / T Q o$ は総流出量低減率 $(\%), T Q 0$ は 雨水浸透施設未設置時の総流出量, $T Q s$ は雨水浸透 施設設置時の総流出量, $\triangle P Q d / P Q o$ はピーク流量の 低減率 $(\%), P Q 0$ は雨水浸透施設未設置時のピーク 流量, $P Q s$ は雨水浸透施設設置時のピーク流量であ る.

透水性舖装のみを設置した場合には総流量、ピー ク流量共にあまり流出抑制効果は得られていない. しかし，浸透連結管を付加することによって，透水 性舗装の浸透能の向上と浸透連結管よりの地下浸透 が行われ，高い流出抑制効果を得られている.

\begin{tabular}{|c|c|c|c|c|}
\hline \multirow{2}{*}{ ケース } & \multirow{2}{*}{$\begin{array}{c}\text { 総流出水量 } \\
\left(\mathrm{m}^{3}\right)\end{array}$} & \multirow{2}{*}{$\begin{array}{c}\text { ピーク流量 } \\
\left(\mathrm{m}^{3} / \mathrm{min}\right)\end{array}$} & \multicolumn{2}{|c|}{ 低減率 (\%) } \\
\hline & & & 総 量 & ピーク \\
\hline $\begin{array}{l}\text { 未設置時 } \\
\text { ケース I } \\
\text { ケース II }\end{array}$ & $\begin{array}{l}4,701 \\
3,806 \\
1,838\end{array}$ & $\begin{array}{r}121.9 \\
96.3 \\
78.4\end{array}$ & $\begin{array}{l}\overline{19} \\
61\end{array}$ & $\begin{array}{l}\overline{21} \\
36\end{array}$ \\
\hline
\end{tabular}

表-4 浸透施設設置による流出抑制効果

\section{6. 結言}

透水性舗装は流出抑制効果を有するが，他の浸透 施設や雨水貯留施設流出抑制効果が不確実なことに より雨水排除計画立案時等においてあまり前向きに 考慮されてこなかった.これに対して，筆者らは透 水性舗装に浸透連結管を付加することにより, 雨水 浸透施設が得意としない降雨後半における流出抑制 効果の保持を目指した. 実規模の実験施設を設置し， その浸透能実験を数年間にわたり実施した. しかし， 実験結果の解析からは，浸透連結管付加による明確 な浸透性舗装の流出抑制保持効果は見いだせなかっ た. そこで, 実験時の透水性舖装と浸透連結管から の流出の状況や各種実験データの解析結果を踏まえ て, 浸透連結管を付加した透水性舗装の浸透機構を 解明し，これをもとにその浸透システムをシミュレ ーションできるモデルを構築した.

浸透連結管を付加した透水性舗装の浸透機構に関 わる各種特性值を実験結果を用いて同定した上で, 同一条件下で浸透連結管を付加した場合としなかっ た場合の浸透状況及び流出抑制状況を予測した。 そ の結果, 透水性舗装一の浸透連結管の付加は, 降雨 後半における流出抑制効果の保持に効果があること を示すことができた.

次に，このような雨水浸透施設を都市域に設置し た場合の排水区域単位での流出抑制効果を，修正 $\mathrm{R}$ R L 法の有効降雨の算定において, 有効降雨モデル に対象浸透施設の浸透機構を表すシミュレーション モデルを組み込む方法により評価した。幹線道路を 除く道路すべてに検討した浸透連結管付き透水性舗 装の設置により，1/10 の確率降雨において総流量を $61 \%$ ，流出ピークを $36 \%$ 低減可能であることを示し た.

これより，透水性舗装では浸透連結管を付加して 路床一の浸透水を適宜排出系に排出すれば，雨水排 除計画における流出抑制施設として勘案できるレべ ルの流出抑制効果を保てることを示せた.

最後に, 本研究の遂行に当たり, 実験施設を提供 していただいた神戸市下水道局の関係各位に哚く謝 意を表すとともに，当調查研究に協力頂いた方々に 


\section{参考文献}

1）高橋徹男, 浪岡俊史, 白鳥悟士（札幌市）：創成川 処理区雨天時流量 - 負荷量解析, 平成 5 年度第 30 回 下水道研究発表会講演集, pp.783-785, 1993.

2）唐牛義夫, 今井健治, 白鳥悟士（札幌市）：札幌市 における雨水貯留管（創成川貯留管），月刊下水道， Vol.16, No.4, pp.21-26, 1993.

3) 大迫健一（東京都）：池尻幹線 - 新駒沢幹線の管渠 内貯留による雨天時初期污濁対策および浸水対策と しての暫定利用, 月刊下水道, Vol.14, No.5, pp.22 $-32,1991$.

4) 山本浩士, 永田俊範（名古屋市）：名古屋市におけ る合流式下水道の改善目標と具体策について，第 31 回下水道研究発表会講演集, pp.814-816, 1994 .

5) 杉浦弘明, 倉敷三樹男, 守屋直哉 : 浸水対策施設を 利用した雨天時污濁の削減効果, 平成 6 年度第 31 回 下水道研究発表会講演集，pp.808-810，1994.

6) 結城庸介（大阪市）：大阪市における大規模雨水貯 留施設, 月刊下水道, pp.37-40, Vol.16, No.4, 1993.4 .

7) 原正博：大規模幹線による雨水対策設計例, 下水道 協会誌，Vol.27, No.312, pp.47-50, 1990.5.

8) 和田安彦, 三浦浩之, 清水俊吾 : 都市域における複 数の雨水浸透型施設による流出抑制のシミュレーシ ヨン予測とその評価, 土木学会衛生工学研究討論会 講演集，第 26 巻，pp.91-96, 1990 .

9）和田安彦, 三浦浩之：雨水浸透型施設の組み合わせ による流出抑制と効果, 日本下水道協会, 第 26 回下 水道研究発表会講演集, pp.809-811, 1989.5 .

10) Yasuhiko Wada and Hiroyuki Miura : Effect and Evaluation of Storm Runoff Control by Permeable
Runoff, 5th International Conference on Urban Storm Drainage, pp.789-794, 1990.

11）和田安彦, 三浦浩之, 松本良博 : 複数の雨水浸透型 施設による雨水流出抑制効果のシミュレーション予 測とその評価，下水道協会誌，Vol.28， №. 330 , pp.25-35, 1991.8.

12）和田安彦, 三浦浩之：浸透性雨水管による雨水流出 抑制と浸透能の評価, 土木学会第 43 回年次学術講演 会概要集, pp.164-165, 1988.10.

13）和田安彦, 三浦浩之：広域雨水流出制御システムに よる雨水流出抑制の効果とその評価, 第 25 回下水道 研究発表会諢演集, pp.680-682, 1988.

14）和田安彦，三浦浩之：広域雨水制御システムによる 雨水流出抑制効果のシミュレーション解析, 平成元 年度土木学会関西支部年次学術講演会講演集, 1989 .

15）和田安彦, 三浦浩之：広域雨水制御システムによる 雨天時流出負荷削减効果のシミュレーション解析, 土木学会第 44 回年次学術講演会概要集, pp.904-905, 1989 .

16) Road Research Laboratory : A Guide for Engineers to the Design of Storm Sewer Systems, Road Note No.35, 1963.

17) Transport and Road research Laboratory : A Guide for Engineers to the Design of Storm Sewer Systems, Road Note No.35, 2nd Ed.

18）山口高志, 松原重昭, 山守隆 : 都市における降雨流 出調查，第 2 報，土木技術資料，14-11，1972。

19）山口高志, 松原重昭, 山守隆：都市における降雨流 出調查，第 3 報，土木技術資料，15-17，1973。

\title{
EVALUATION OF AN EFFECT OF A POROUS ASPHALT PAVEMENT TO ADD AN INFILTRATION PIPE ON RUNOFF CONTROL
}

\author{
Yasuhiko WADA and Hiroyuki MIURA
}

\begin{abstract}
We examined the possibility of improvement in a porous asphalt pavement for runoff control by the installation of a infiltration pipe under the pavement. From the result of many infiltration experiments at our experimental rainfall infiltration facilities, it made clear that the infiltration rate through the porous asphalt pavement is influenced by the volume of pore and permeability of the pavement and if storm water puddled on the surface of the pavement then rainfall infiltration becomes fast. And the construction of the infiltration pipe under the porous asphalt pavement will improve the final infiltration rate of the infiltration pavement about $5 \mathrm{~mm} / \mathrm{hr}$. Furthermore, we build up a model which can simulate rainfall infiltration and runoff at the infiltration pavement with the infiltration pipe based on infiltration process in the pavement and infiltration pipe. By this model, we prove that the construction of the infiltration pavements with infiltration pipes is one of effective storm runoff control facilities in urban area.
\end{abstract}

